http://ejournal.poltekkes-smg.ac.id/ojs/index.php/link

\title{
KEGIATAN REVITALISASI KELAS IBU HAMIL (KERTAS BUMIL)
}

\author{
Risqi Dewi Aisyaha* ${ }^{*}$; Fitriyani ${ }^{b}$; Lia Dwi Prafitri ${ }^{c}$ \\ a, b, c Fakultas Ilmu Kesehatan, Universitas Muhammadiyah Pekajangan Pekalongan \\ Jl. Raya Ambokembang No 8 Pekalongan 51172
}

\begin{abstract}
Abstrak
Kelas ibu hamil adalah salah satu upaya untuk dapat memberikan pengetahuan yang cukup kepada ibu hamil dan keluarga. Kelas ibu hamil merupakan kegiatan pemberdayaan masyarakat melalui sarana belajar kelompok tentang kesehatan ibu hamil melalui pemanfaatan buku KIA. Dukuh papagan adalah dukuh yang padat penduduk dengan tingkat pendidikan masyarakatnya yang rata-rata rendah yakni tamat sekolah dasar. Tujuan kegiatan pengabdian ini adalah revitalisasi kelas ibu hamil untuk meningkatkan kesehatan ibu dan anak. Hasil pengabdian ini adalah terbentuknya kembali kelas ibu hamil. Kelas ibu hamil tetap berjalan dengan kerjasama warga, puskesmas, bidan, kader, dan ibu hamil. Kelas ibu hamil tetap berjalan sebulan sekali dengan dana iuran sendiri dari ibu hamil untuk snack karena kesadaran pentingnya pengetahuan selama kehamilan. Rencana Tindak Lanjut adala keberlangsungan kelas ibu amil dengan pemateri bisa dari bidan atau dari instititusi pendidikan kebidanan.
\end{abstract}

Kata Kunci : Kelas ibu hamil, bidan, hamil

\begin{abstract}
[MATERNITY CLASS REVITALIZATION ACTIVITIES] The class of pregnant women is one of the efforts to be able to provide sufficient knowledge to pregnant women and families. The class of pregnant women is a community empowerment activity through the means of learning groups about the health of pregnant women through the utilization of KIA books. Dukuh papagan is a densely populated dukuh with a low level of community education i.e. elementary school. The purpose of this devotional activity is the revitalization of the class of pregnant women to improve maternal and child health. The result of this devotion is the re-establishment of the class of pregnant women. The class of pregnant women continues to run with the cooperation of residents, health centers, midwives, cadres, and pregnant women. The class of pregnant women still runs once a month with its own dues from pregnant women for snacks due to awareness of the importance of knowledge during pregnancy. Follow-up plan for the continuity of maternal classes with presenters can be from midwives or from midwifery education.
\end{abstract}

Keywords: Antenatal clas, midwives, pregnant

\section{Pendahuluan}

Tingginya AKI disebabkan antara lain disebabkan karena ketidak berdayaan seorang ibu dalam memutuskan untuk mendapat pertolongan medis ketika menghadapi permasalahan terkait ibu dan bayinya. Hal ini disebabkan antara lain karena kurangnya pengetahuan ibu mengenai perawatan selama kehamilan serta pengenalan tanda bahaya obsetri dan neonatal, sehingga akan menghambat suatu

*) Correspondence Author (Risqi Dewi Aisyah)

E-mail: aisyahrisqidewi@gmail.com keputusan yang diambil. Untuk dapat meningkatkan pengetahuan masyarakat diperlukan adanya penyuluhan. Dewasa ini banyak penyuluhan yang dilakukan perseorangan atau kasus per kasus yang diberikan petugas lain pada saat pemeriksaan kehamilan atau posyandu. Namun demikian, kegiatan tersebut dirasa kurang optimal, karena pengetahuan yang diberika seputar kasus yang dialami aja (Mersal et al., 2013)

Kelas ibu hamil adalah salah satu upaya untuk dapat memberikan pengetahuan yang 
cukup kepada ibu hamil dan keluarga. Kelas ibu hamil merupakan kegiatan pemberdayaan masyarakat melalui sarana belajar kelompok tentang kesehatan ibu hamil melalui pemanfaatan buku KIA. Kegiatan kelas ibu hamil ini melibatkan suami dan keluarga sehingga dapat memahami kondisi ibu hamil sampai dengan melahirkan dan merawat bayinya (Kemenkes RI, 2014).

Pemberian pendidikan dan pengetahuan sebelum persalinan menjadi bekal untuk orang tua dalam mempersiapan keahiran anaknya dan persiapan menjadi orang tua. Pendidikan dengan menggunakan kelas ibu hamil dapat memnberikan pemahaman mengenai kebutuhan emosional, psikologis dan fisik selama kehamilan, persalinan dan nifas (Svensson et al., 2008)

Pendidikan selama kehamilan adalah komponen penting dari perwatan selama kehamilan. Pada kenyataannya calon orang tua selalu mencari informasi mengenai kehamilan dan persalinan serta bersedia menghadiri terutama di minggu-minggu terakhir kehamilan (Brixval et al., 2015)

Pemberian pengetahuan yang luas selama kehamilan dan mencakup hasil yang berhubungan dengan kehamilan, kelahiran dan orang tua. Pengaruh pendidikan antenatal dalam kelompok, dengan partisipasi dari sejumlah kecil peserta, akan memberi efek bentuk lain dari pneyuluhan kesehatan diantaranya ada dinamika kelompok, sesi tanya jawab yang akan menambah pengetahuan seluruh peserta kelas ibu hamil (Koushede et al., 2017)

Berdasarkan laporan P4K Puskesmas Kedungwuni I Bulan Desember tahun 2015 ada 21 ibu hamil (2,3\%) dari 900 ibu hamil yang menjadi sasaran ibu hamil yang termasuk ke dalam potensi gawat dan mengalami tanda bahaya. Kelurahan Kedungwuni Barat salah satu wilayah puskesmas Kedungwuni I, berdasarkan data Januari-Maret 2016 terjadi angka kematian bayi 5 (25\%) dari 20 persalinan.

Dukuh Papagan juga salah satu dukuh di Kelurahan Kedungwuni Barat yang menjadi mitra dalam kegiatan IbM ini. Dukuh papagan adalah dukuh yang padat penduduk dengan tingkat pendidikan msayarakatnya yang rata-rata rendah yakni tamat sekolah dasar. Pada bulan Januari-Maret 2016 angka kematian bayi di dukuh ini ada 3 orang (15\%) dari 20 persalinan. Jumlah ibu hamil di bulan Maret 2016 ini sejumlah 9 orang dengan jumlah ibu hamil resti $11 \%$ (1 orang) dan semua berkunjung ke posyandu. AKB yang terjadi tidak luput dari perawatan selama kehamilan.

\section{Metode}

\section{Pelaksanaan kegiatan}

Untuk mengatasi masalah tersebut kami menawarkan pendekatan untuk melakukan kegiatan pengabdian masyarakat dalam bentuk kegiatan revitatlisasi kelas ibu hamil untuk meningkatkan kesehatan ibu dan anak di Dukuh Papagan Kelurahan Kedungwuni Barat Kecamatan Kedungwuni. Kegiatan ini akan dilakukan dalam kurun waktu 6 bulan dan dilaksanakan 1 bulan sekali (Maret - Agustus 2018). Dalam pelaksanaan kegiatan kami memberikan informasi, edukasi serta praktik secara langsung sehingga ibu hamil dapat langsung mengaplikasikan informasi-informasi dengan berbagai perlengkapan dan peralatan yang telah disediakan.

\section{Prosedur kerja :}

a. Pengenalan pentingnya kelas ibu hamil pada mitra untuk peningkatan motivasi merevitalisasi kelas ibu hamil

b. Mengadakan musyawarah mufakat untuk revitalisasi kelas ibu hamil dengan ketersediaan tempat, sarana dan prasarana, dana

c. Merevitalisasi kembali kelas ibu hamil

d. Menyiapkan tempat dan sarana prasarana yang telah disepakati

e. Mempersiapkan alat bantu penyuluhan dan jadwal pelaksanaan kegiatan kelas ibu hamil serta materi yang akan disampaikan.

f. Pemberian penyuluhan kesehatan yang tercakup dalam panduan kelas ibu hamil

g. Penggunaan media penyuluhan yang menarik berbasis teknologi

h. Monitoring dan evaluasi kegiatan pada pertengahan kegiatan dan akhir kegiatan

\section{Partisipasi Mitra :}

a. Berperan aktif dalam rencana kegiatan revitaslisasi mendatangi musyawarah dalam rangka membahas kegiatan revitalisasi kelas ibu hamil

b. Menyediakan tempat untuk terlaksananya kelas ibu hamil

c. Mengikuti kelas ibu hamil dengan aktif dan membawa buku KIA

d. Memiliki kesepakatan untuk penyediaan dana dan keberlangsungan kelas ibu hamil saat IbM berakhir 


\section{Evaluasi Program}

a. Dilihat jumlah kehadiran mitra dalam pelaksanan kegiatan revitalisasi ibu hamil

b. Pada pertengahan program di evaluasi berlangsungnya kelas ibu hamil dari tempat, sarana prasarana, konsumsi dan pendanaan

c. Melihat peningkatan pengetahuan ibu hamil tentang materi yang diberikan pada akhir setiap sesi peretemuan dan review pada saat sesi awal pertemuan berikutnya selama kelas ibu hamil

d. Evaluasi setelah program IbM selesai di lapangan, keberlangsungan kelas ibu hamil, penyediaan dana dari ibu hamil sendiri

\section{Hasil dan Pembaasan}

a. Pelaksanaan Kegiatan

Pelaksanaan Kegiatan pengabdian ini sesuai dengan target waktu yang direncanakan, pada saat proses pelaksanaan mulai dari pendekatan hingga berakhirnya kegiatan semua berjalan lancar dan mendapat antusiasme dari puskesmas dan kepala desa.

b. Dukungan Mitra

Bentuk dukungan mitra yang diberikan antara lain berperan aktif dalam kegiatan dari awal hingga proses akhir. Bentuk dukungan puskesmas diwakili oleh bidan desa selalu hadir dan membantu melakukan advokasi kepada ibu hamil dan warga. Kader juga menyediakan tempat untuk pelaksanaan kegiatan tersbut dipih tempat yang mudah dijangkau oleh ibu-ibu hamil. c. Kondisi dan Situasi Sasaran

Kondisi ibu hamil pada sat mengikuti setiap kelas ibu hamil yang diadakan sangat fit. Ibu hamil sangat antusias mendengarkan materi, membawa buku KIA dan bertanya tentang materi atau di luar materi yang berkaitan dengan kondisi atau untuk memenuhi rasa keingintahuan mereka tentang kehamilan dan persalinan. Ibu hamil selalu datang tepat waktu, sesuai dengan kesepakatan setiap akhir pertemuan, ketika ditanya tentang materi yang sebelumnya, ibu hamil juga masih mengingat materi tersebut. Hal ini dapat ditarik keseimpulan bahwa ilmu yang sudah didapatkan di ingat dan dipahami oleh sasaran.

d. Hasil untuk Mitra

Hasil pengabdian ini adalah terbentuknya kembali kelas ibu hamil, sebelumnya kelas ibu hamil ada tapi hilang dikarenakan tidak adanya dana untuk penyediaan snack dan makan. Kelas ibu hamil terus berlangsung karena dari awal kita membentuk kembali dengan kesepakan setiap kali kelas ibu hamil, ibu hamil membawa uang 5000 rupiah yang dipergunakan untuk snack sendiri, sehingga setelah selesainya kegiatan ini, kelas hamil tetap berlanjut dengan meningkatnya kesedaran ibu hamil pentingnya mendapatkan pengetahuan-pengetahuan tentang kehamilan dan persalinan.

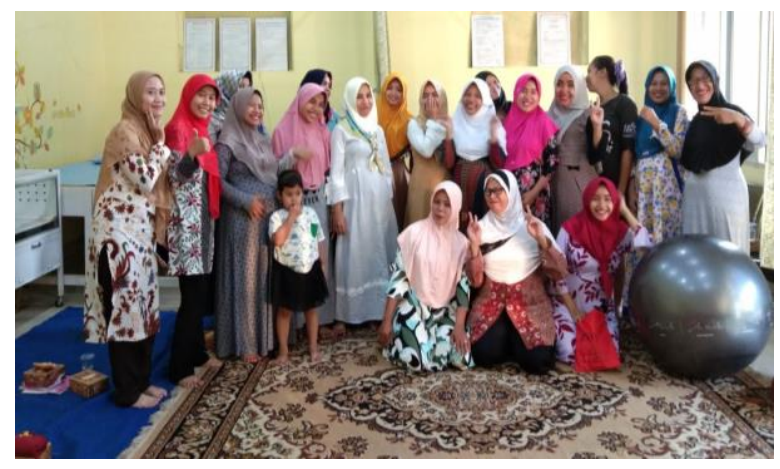

Gambar 1. Pelaksanaan Kelas Ibu Hamil Pertama

Kegiatan ini meneganlakan kembali kelas ibu amil dengan pemberian materi nutrisi ibu hamil. Apa yang dimakan seorang wanita ketika dia hamil dapat memiliki efek mendalam dan berlangsung pada kesehatan dan kesehatan anaknya. Janin berevolusi dalam 9 bulan. Sementara itu, ibu harus menjalani urutan dramatisnya sendiri perubahan fisiologis. Efek dari tidak memadai atau asupan nutrisi berlebih dapat diamati di jangka pendek dan panjang. Oleh karena itu, bagi janin untuk memulai dan melanjutkan kesehatan, semua nutrisi yang diperlukan harus tersedia dalam jumlah yang tepat pada waktu mereka dibutuhkan (Koenig, 2017). Status gizi ibu berperan penting terhadap pertumbuhan dan perkembangan janin. Gizi salah selama kehamilan akan memberikan pengaruh negatif bahkan konsekuensi jangka panjang terhadap bayi yang dilahirkan (Rahfiludin \& Dharmawan, 2019)

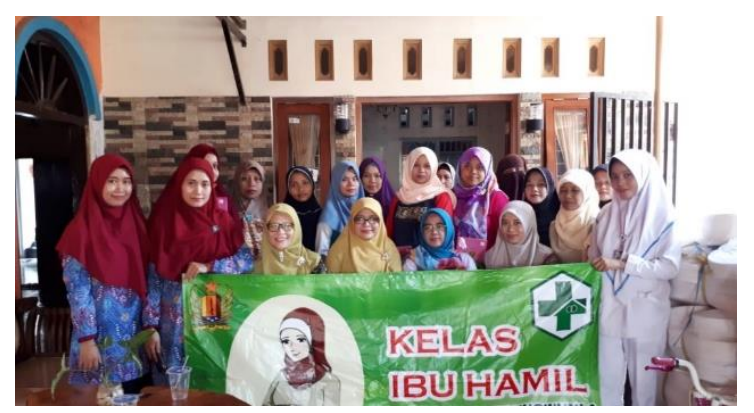

Gambar 2. Pertemuan kelas ibu hamil ke 2 dengan materi anemia dalam kehamilan dan persiapan persalinan 
Salah satu upaya untuk mencegah keterlambatan penanganan adalah dengan adanya kesiapan persalinan. Adanya kesiapan persalinan dapat dilakukan dengan mempersiapkan rencana kelahiran dan mempersiapkan rencana jika terjadi komplikasi pada persalinan ibu. Mempersiapkan rencana kelahiran adalah rencana yang dibuat oleh ibu, bapak dan petugas pelayanan kesehatan untuk mengidentifikasi penolong dan tempat bersalin, serta perencanaan tabungan untuk mempersiapkan biaya persalinan. Kemudian keluarga juga perlu mempersiapkan rencana jika terjadi komplikasi pada persalinan ibu, seperti mengidentifikasi tempat rujukan dan transportasi untuk mencapai tempat tersebut, mempersiapkan donor darah, mengadakan persiapan finansial serta mengidentifikasi pembuat keputusan pertama dan pembuat keputusan kedua jika pembuat keputusan pertama tidak ada di tempat (Forbes et al., 2018)

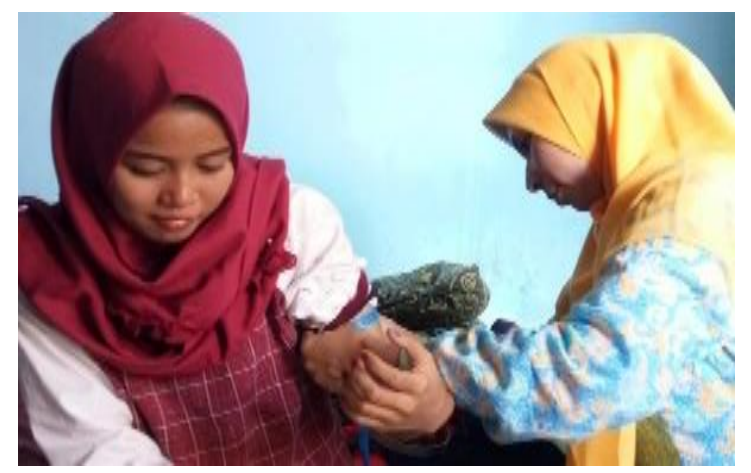

Gambar 3 Pemeriksaan Lingkar lengan atas

Hasil pemeriksaan tekanan darah dan berat badan ibu hamil semua dalam batas yang normal.

Tabel 1 Hasil Pemeriksaan Lila (Lingkar lengan Atas)

\begin{tabular}{lll}
\hline Lila $(\mathbf{c m})$ & Frek & \% \\
\hline Tidak KEK $(\geq 23,5)$ & 17 & 85 \\
KEK $(<23,5 \mathrm{~cm})$ & 3 & 15 \\
\hline
\end{tabular}

Hasil pemeriksaan menujukkan $85 \%$ ibu hamil yang mengikuti kelas ibu hamil tidak mengalami Kekurangan Energi Kronis atau KEK. Hal tersebut sudah bagus karena status gizi ibu pada masa kehamilan adalah faktor kunci untuk pertumbuhan dan perkembangan janin, jadi diet sehat dan seimbang sangat penting baik sebelum dan selama kehamilan. Selama kehamilan, ibu menyediakan energi dan nutrisi untuk dirinya sendiri dan pertumbuhan janin serta persiapan menyusui.(Castrogiovanni \& Imbesi, 2017)
Pengukuran status gizi ibu hamil dilakukan dengan mengukur Lingkar Lengan Atas (Lila), Salah satu indetifikasi ibu hamil dengan Kekurangan Energi Kronik (KEK) adalah memiliki ukuran Lingkar Lengan Atas. Ibu hamil yang mengalami masalah gizi akan berdampak buruk terhadap kesejahteraan ibu maupun bayinya dan kualitas bayi yang akan dilahirkan (Fitriyani et al., 2020)

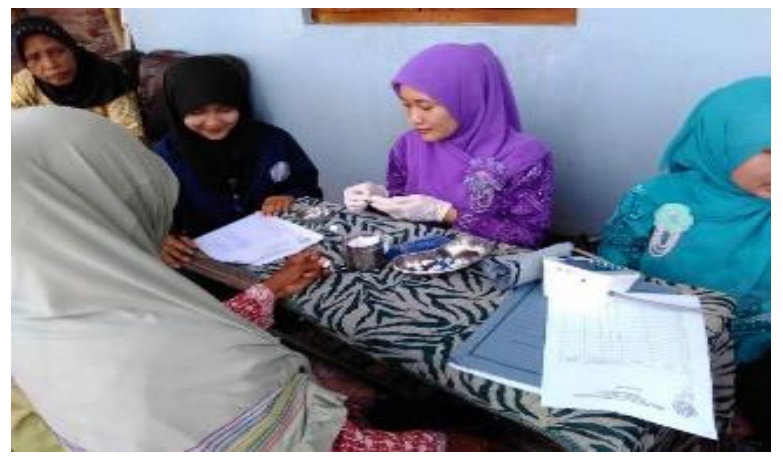

Gambar 4 Pemeriksaan $\mathrm{Hb}$

Tabel 2 Hasil Pemeriksaan $\mathrm{Hb}$

\begin{tabular}{lll}
\hline Kategori Anemia & Frek & $\mathbf{\%}$ \\
\hline Tidak Anemia & 16 & 80 \\
KEK $(<23,5 \mathrm{~cm})$ & 4 & 20 \\
\hline
\end{tabular}

Hasil pemeriksaan menujukkan 20\% menujukkan ibu hamil mengalami anemia dan termasuk dalam kategori anemia ringan (9-10 gr\%). Wanita yang rutin periksa empat atau lebih kali selama kehamilan mereka akan mengurangi angka kejadian anemia. Selain itu, kami percaya bahwa wanita hamil yang sering mengunjungi klinik antenatal akan mengembangkan anemia selama kehamilan mereka karena deteksi anemia pada kunjungan pertama, pendidikan gizi rutin, zat besi dan suplementasi asam folat, dan rujukan ke dokter jika ada temuan abnormal. Jumlah kunjungan perawatan antenatal menunjukkan hubungan yang kuat dengan anemia yang akan bermanfaat untuk pelayanan pada awal kehamilan. Menjaga berat badan yang sehat, membuat awal dan tepat waktu kunjungan ke klinik antenatal akan membantu untuk menurunkan prevalensi anemia pada kehamilan perempuan. Selain itu, penyuluhan kesehatan tentang diet nutrisi sehat dan besi suplementasi pada semua wanita usia reproduksi terbukti menjadi bermanfaat (Aisyah \& Fitriayani, 2016)

Luaran lain yang kami dapatkan adalah meningkatnya kesadaran dan pemahaman ibu hamil, sehingga pengetahuan ibu hamil meningkat dan dapat mencegah serta mendeteksi secara dini ada tidaknya kegawatdaruratan yang 
dialami. Pendidikan prenatal dirancang untuk memberikan pengetahuan dan ketrampialan yang dibutuhkan selama kehamilan dan persalinan serta untuk mempersiapkan pengasuhan anak secara dini (Ontario, 2013)

Tujuan kelas ibu hamil spesifik mencakup peningkatan pengetahuan mengenai kehanmilan, proses persalinan, pereda nyeri persalinan dan intervensi kebidanan, perawatan payudara, nutrisi dan kepercayaan diri untuk melahirkan dan menjadi orang tua serta pencegahan depresi post partum. Selain itu promosi kesehatan dan pengurangan risiko adalah tujuan penting dari kelas ibu hamil. Bertemu dengan orang lain di situasi yang sama dan mengembangkan jejaring sosial adalah salah satu tujuan lain dai kelas ibu hamil (Gluck et al., 2018)

Salah satu manfaat kelas hamil juga dapat mengurangi kecemasan menjelang persalinan, dengan adanya pendidikan atau edukasi selama dilaksanakannya kelas hamil tersebut. Hasil peneltian Aisyah, RD (2019) menyebutkan bahwa pemberian edukasi didalam paket caring dapat mngurangi kecemasan menjelang persalinan (Aisyah et al., 2019)

e. Rencana Tindak Lanjut

Rencana tindak lanjut dari kegiatan pengabdian ini adalah keberlangsungan dari kelas ibu hamil. Kelas ibu hamil tetap berjalan dengan kerjasama warga, puskesmas, bidan, kader, dan ibu hamil. Kelas ibu hamil tetap berjalan sebulan sekali dengan dana iuran sendiri dari ibu hamil untuk snack karena kesadaran pentingnya pengetahuan selama kehamilan. Pemberian pengetahuan bisa dilakukan oleh bidan atau puskesmas dan sesekali juga meminta bantuan dari tenaga pendidikan untuk pemebrian pengtahuan, konsultasi kesehatan. Tempat disediakan oleh warga setempat diwakili oleh kader dan terjangkau oleh semua ibu hamil. Disepakati bersama dengan mitra untuk rencana tidank lanjut pengabdian ini:

1) Waktu pelaksanaan kelas ibu hamil: satu bulan sekali yaitu setiap hari Jumat minggu pertama

2) Tempat pelaksanaan: Rumah Ibu Hamil bergantian, Rumah Bidan Desa, Rumah Bu Kades, Rumah kader kesehatan bergantian setiap pelaksanaanya

3) Materi: diberikan oleh tenaga kesehatan baik bidan, ahli gizi dari puskesmas, dan sesekali dari tenaga pendidikan tetap mengisi untuk kegiatan pengabdian masyarakat ini

4) Biaya: masing-masing ibu hamil membawa uang lima ribu rupiah untuk konsumsumsi sendiri
5) Penanggung jawab kegiatan adalah bidan desa.

6) Monitoring dan Evaluasi: Monitoring dan evaluasi tetap kami lakukan setiap tiga bulan sekali bekerja sama dengan puskesmas agar kegiatan kelas ibu hamil tetap berlangsung

\section{Simpulan dan Saran}

Desa Papagan ini dapat merevitaslisasi kembali kelas ibu hamil. Kelas ibu hamil mulai berjalan kembali dengan kerjasama dari semua pihak terkait. Tujuan dari kelas ibu hamil juga tercapai yaitu peningkatan pengetahuan, kesadaran dan pemahaman mengenai kehamilan, persalinan dan nifas serta ibu hamil dan tenaga kesehatan dalam hal ini bidan mampu bekerja sama untuk mendeteksi adanya resiko sehingga mencegah terjadinya kegawatdaruratan. Saran agar bidan, kader dan warga dapat menjaga keberlangsungan kelas ibu hamil.

\section{Ucapan Terima Kasih}

Ucapan terimakasih kami sampaikan kepada lembaga penelitian dan pengabdian Universitas Muammadiyah Pekajangan yang telah mendanai pengabdian ini, terimaksih kepada seluru mitra yakni Bidan Desa, Puskesmas Kedungwuni I, Ibu Hamil yang tela bekerjasama dalam pengabdian ini dan tetap menindaklanjuti keberlangsungan kelas ibu hamil ini.

\section{Daftar Pustaka}

Aisyah, \& Fitriayani. (2016). Faktor - faktor internal dan Eksternal yang berhubungan dengan kejadian anemia di wilayah kabupaten pekalongan. Jurnal Motorik, 11, 41-49.

Aisyah, R. D., Suparni, S., \& Fitriyani, F. (2019). Abstrac Abstrak. 08, 15-20.

Brixval, C. S., Axelsen, S. F., Lauemøller, S. G., Andersen, S. K., Due, P., \& Koushede, V. (2015). The effect of antenatal education in small classes on obstetric and psycho-social outcomes - a systematic review. Systematic Reviews, 4(1), 1-9. https://doi.org/10.1186/s13643-015-0010-x

Castrogiovanni, P., \& Imbesi, R. (2017). The role of malnutrition during pregnancy and its effects on brain and skeletal muscle postnatal development. Journal of Functional Morphology and Kinesiology, 2(3). https://doi.org/10.3390/jfmk2030030

Fitriyani, F., Aisyah, R. D., \& Prafitri, L. D. (2020). "Peduli Generasi Penerus Bangsa, Peduli 
Pada Awal Kehidupannya" Dengan Pendampingan Ibu Hamil Dan Balita Dua Tahun (Baduta). Link, 16(1), 6-11. https://doi.org/10.31983/link.v16i1.5570

Forbes, L. E., Graham, J. E., Berglund, C., \& Bell, R. C. (2018). Dietary change during pregnancy and women's reasons for change. Nutrients, 10(8), 1-10. https://doi.org/10.3390/nu10081032

Gluck, O., Hiaev, Z., Rubinstein, H., Bar, J., \& Kovo, M. (2018). 761: The impact of childbirth education classes on delivery outcome. American Journal of Obstetrics and Gynecology, 218(1), S456. https://doi.org/10.1016/j.ajog.2017.11.293

Koenig, M. D. (2017). Nutrient Intake During Pregnancy. JOGNN - Journal of Obstetric, Gynecologic, and Neonatal Nursing, 46(1), 120122.

https://doi.org/10.1016/j.jogn.2016.11.004

Koushede, V., Brixval, C. S., Thygesen, L. C., Axelsen, S. F., Winkel, P., Lindschou, J., Gluud, C., \& Due, P. (2017). Antenatal smallclass education versus auditorium-based lectures to promote positive transitioning to parenthood - A randomised trial. PLoS ONE, 12(5), $1-17$. https://doi.org/10.1371/journal.pone.0176 819

Mersal, F. A., Esmat, O. M., \& Khalil, G. M. (2013). Effect of prenatal counselling on compliance and outcomes of teenage pregnancy. Eastern Mediterranean Health Journal, 19(1), 10-17. https://doi.org/10.26719/2013.19.1.10

Ontario, G. (2013). $\square$ e Evidence for Prenatal Education. 1-7.

Rahfiludin, M. Z., \& Dharmawan, Y. (2019). JOURNAL OF PUBLIC HEALTH FOR TROPICAL AND COASTAL Description of Daily Nutritional Intake of Pregnant Women in Temanggung District, Central Java, Indonesia . 1.

Svensson, J., Barclay, L., \& Cooke, M. (2008). Effective Antenatal Education: Strategies Recommended by Expectant and New Parents. Journal of Perinatal Education, 17(4), 33-42.

https://doi.org/10.1624/105812408×364152 